\title{
Morphological and Molecular Characterization of Gastrointestinal Nematodes in Sheep
}

\author{
M. Veena ${ }^{1 *}$, G. C. Puttalakshmamm ${ }^{1}$, K. J. Ananda ${ }^{2}$ and P. P. Sengupta ${ }^{3}$ \\ KVAFSU, Department of Parasitology, Veterinary College, Hassan-573202, Karnataka, India \\ *Corresponding author
}

\section{A B S T R A C T}

\begin{tabular}{|l|}
\hline Ke y w o r d s \\
Haemonchus \\
contortus, \\
Trichostrongylus \\
colubriformis, \\
$\begin{array}{l}\text { PCR, Anthelmintic } \\
\text { resistance, ITS-2 }\end{array}$ \\
\hline Article Info \\
\hline $\begin{array}{l}\text { Accepted: } \\
\text { 22 March 2020 } \\
\text { Available Online: } \\
10 \text { April } 2020\end{array}$ \\
\hline
\end{tabular}

A study was set out to investigate the distribution of gastrointestinal nematode parasites in sheep farms of Hassan district, Karnataka and to ascertain which species are involved in the anthelmintic resistance. In the study 26 farms were treated with fenbendazole and 19 farms were treated with ivermectin. The pre and post treatment faecal cultures were prepared for each farms. The larvae identified in the pre-treatment faecal culture were Haemonchus sp, Trichostrongylus sp, Oesophagostomum sp, Bunostomum sp and Cooperia $\mathrm{sp}$ based on the morphological keys. During the study 15 farms showed resistance to fenbendazole whereas 2 farms were resistant to ivermectin. Among 15 farms, 12 farms had Haemonchus sp as a predominant larvae followed by Trichostrongylus sp in 3 farms. The ivermectin resistant farms had Haemonchus sp as pre dominant larvae. The post treatment faecal cultures revealed Haemonchus sp. as the predominant gastrointestinal nematode followed by Trichostrongylus sp. The ones mentioned were identified as Haemonchus contortus and T. colubriformis by PCR. The PCR tool used for epidemiological studies supported the investigations of conventional parasitological techniques.

\section{Introduction}

Gastrointestinal parasitism is of considerable importance to sheep farmers worldwide. Being the limiting factor of sheep productivity, gastrointestinal nematodes (GIN) have a highly detrimental effect on the sheep industry (Coop and Holmes, 1996; Jones, 2001), resulting in significant economic losses in meat and wool production, as well as in sheep reproduction (Levya et al., 1982; Urquhart et al., 1996; Hayat et al., 1996; Suarez et al., 2009). Clinical signs and sequelae are dependent on the parasite fauna present and the intensity of infection.

In sheep, these can range from subclinical weight loss to lethal pathologies such as anaemia, diarrhoea and severe protein loss (Pugh and Baird, 2012). 
Anthelmintics are commonly used to control gastrointestinal nematodes. The wide spread use of these drugs and misuse have led to the development of anthelmintic resistance against GINs (Singh and Yadav, 1997) posing serious limitation on the use of anthelmintics. The ability to manage both parasitic disease and anthelmintic resistance is dependent on an understanding of parasite epidemiology, which in turn requires the accurate identification of the parasite species involved (Coles et al., 2006; Sweeny et al., 2012).

To date, identification of nematode parasite species has been generally based on the morphology and morphometry of adult male worms (Soulsby 1971). The sacrificing of animals to obtain adult worms cannot normally be justified, so the most commonly used practice is the microscopic differentiation of infective stage larvae $\left(\mathrm{L}_{3}\right)$ extracted from faecal cultures (Lancaster and Hong 1987; Van Wyk et al., 2004; Coles et $a l ., 2006)$. This is useful in the identification of the gastrointestinal nematode genera. Differentiation of the nematodes by larval stages has limitations. There is overlap of many of the morphological characters between the larvae, through which it is difficult to identify the larvae in mixed infections.

Advances in molecular biology have made it possible to rapidly identify the infective larvae to the species level by using PCR. Molecular methods provide a level of parasite identification beyond what is possible with morphology alone. They play an important role in identifying and differentiating parasites when their morphologic features are ambiguous or altered.

The aim of the current study was to understand the distribution of the infective larvae involved in the gastrointestinal nematode infection throughout the Hassan district, Karnataka by morphological and molecular characterization.

\section{Materials and Methods}

Per rectal faecal samples or freshly voided faecal pellets were collected from the naturally infected animals from different taluks of Hassan district, Karnataka on day zero before treatment and then day 10 after treatment from the animals treated with fenbendazole and day 15 from the animals treated with ivermectin. Qualitative faecal sample examination using sedimentation method and standard salt floatation technique (Soulsby, 19982) were carried out for the presence of strongyle eggs. The positive samples were subjected to quantitative faecal examination by modified McMaster's technique (Coles et al., 1992). The animals having eggs per gram (EPG) of faeces more than 150 were selected for the study.

From each farm pre and post treatment faecal culture was prepared. The cultures were incubated in moist conditions for approximately 14 days at $27^{\circ} \mathrm{C}$. The larvae were then harvested and identified using the morphological keys (Van Wyk and Mayhew, 2013). The percentage generic composition of the cultures was determined from a random examination of 100 larvae.

\section{Morphological characterization}

\section{Isolation of larvae}

The faecal mixture was made with optimum consistency and placed on the top of a small inverted petri plate which in turn was placed in a larger petri dish covered with a lid. The space between inverted small petri dish and large petri dish is filled with water up to the level of faeces creating a water pocket between two petri dishes. Larvae were collected after 14 days from the petri dish 
without disturbing the mass. The fluid thus obtained was clear, subjected to centrifugation at $1,000 \mathrm{rpm}$ and sediment obtained was examined for larval morphology.

\section{Larva preparation for identification}

The shape of the larvae were preserved by adding $2 \%$ formalin and tubes containing the larvae were heated gently with bunsen burner. By this step, larvae were dead but preserved intact and stained well to ease the identification of morphological characters. A drop of larval su spension was taken on a clean glass microscopic slide and Lugol's iodine $(2 \%)$ solution that is pre-diluted was added. The prepared slide was left for few minutes, then observed under the microscope for detailed internal structures of the larvae and photographed.

\section{Larval identification}

Strongyle larvae $\left(\mathrm{L}_{3}\right)$ were identified to the genus level on the basis of morphological characteristics (Van wyk and Mayhew, 2013). In each case 100 randomly selected $L_{3}$ were identified. The total length of the larvae, tail length and shape, presence or absence of tail sheath, type of oesophagus and number of intestinal cells in third stage larvae were considered for identification.

\section{Molecular characterization}

\section{DNA template preparation}

A minimum of 5 pre dominant larvae identified on the basis of morphological keys were picked from each culture. The larvae were exsheathed by incubating in 3.5\% Sodium hypochlorite (aqueous solution, 4\% active chlorine) for 5-20minutes. The exsheathed larvae were washed in distilled water for 3-5 times and then used for DNA extraction. The genomic DNA was extracted from the infective larvae using a commercial kit (HiPurA $^{\mathrm{TM}}$ Multi-Sample DNA purification kit - Himedia) as per the manufacturer's instructions. The DNA was stored at $-20^{\circ} \mathrm{C}$ until used as a template for species identification of gastrointestinal nematodes.

\section{Polymerase chain reaction}

PCR was carried out in a thin wall PCR tubes in $25 \mu 1$ reaction volume using a commercial PCR master mix (Hi-Chrom PCR Master Mix- MBT089) and genomic DNA. The amplification was carried out using the PCR Thermal cycler (MJMini ${ }^{\mathrm{TM}}$ Personal thermal cycler, Bio-Rad Technologies). Samples without genomic DNA were used as negative controls.

The amplicons were electrophoresed using $1.5 \%$ agarose gel and the DNA migration and resolution pattern was examined by UV trans illumination technique and the picture was documented by photography.

\section{Haemonchus contortus}

The primers targeting unique sequence motifs present in the second internal transcribed spacer region- 2 (ITS-2) of the ribosomal DNA were used. PCR was carried out using species specific forward and universal reverse primer to strongylide species published by Bottet.al, 2009. The primer sequences used were:

1. HAE forward primer: 5 CAAATGGCATTTGTCTTTTAG 3'

2. HAE Reverse primer: 5' TTAGTTTCTTTTCCTCCGCT 3

The reaction was carried out with the following conditions: Initial denaturation at $94^{\circ} \mathrm{C}$ for 5 minutes, followed by 35 cycles of 
$94^{\circ} \mathrm{C}$ for $30 \mathrm{~s}$ (denaturation), $55^{\circ} \mathrm{C}$ for $30 \mathrm{~s}$ (annealing) and $72^{\circ} \mathrm{C}$ for $30 \mathrm{~s}$ (extension), followed by a final extension at $72{ }^{\circ} \mathrm{C}$ for 7 minutes (Bott et al., 2009 and Tan et al., 2014).

\section{Trichostrongylus sp}

A species specific, multiplexed PCR technique developed by Waghorn et al., 2013 was used for identification of the Trcihostrongylus sp. larvae. The primers targeting the second internal transcribed spacer region (ITS-2) of the ribosomal DNA were used to identify the larva. The species specific primers for Trichostrongylus colubriformis and T. axei along with the two generic primers used in the multiplex PCR reaction are presented in Table 1 .

Touchdown cycling conditions used were: $95^{\circ} \mathrm{C}$ for 8 minutes, 12 cycles of $94^{0} \mathrm{C}$ for 15 seconds, $60^{\circ} \mathrm{C}$ (reducing by $0.5^{\circ} \mathrm{C}$ per cycle) for 15 seconds, $72^{0} \mathrm{C}$ for 30 seconds, 25 cycles of $94^{0} \mathrm{C}$ for 15 seconds, $54^{\circ} \mathrm{C}$ for 15 seconds, $72^{\circ} \mathrm{C}$ for 30 seconds followed by a final extension at $72^{\circ} \mathrm{C}$ for 7 minutes. Specific product sizes of $398 \mathrm{bp}$ for Trichostrongylus $s p$ and $232 \mathrm{bp}$ for $T$. colubriformis were amplified (Figure 7).

\section{Oesophagostomum sp}

Polymerase chain reaction was performed separately using genus specific and species specific primers

\section{Genus specific PCR assay}

The primers designed targeting the internal transcribed spacer-2 (ITS-2) with upstream flanking region about $117 \mathrm{bp}$ of ribosomal DNA (rDNA) and the cycling conditions developed by Kumar et al., 2018 were used in the study.

\section{Genus specific primer sequence}

Oeso forward: 5' TCG ACT AGC TTC AGC GAT G 3'

Oeso reverse: 5'CCA AAG CAT TCT TAG TCG CT 3'

Polymerase chain reaction was performed with the following conditions: Initial denaturation at $94^{\circ} \mathrm{C}$ for two minutes was followed by 36 cycles each at $94^{\circ} \mathrm{C}$ for $30 \mathrm{~s}$, $53^{\circ} \mathrm{C}$ for $30 \mathrm{~s}$ and $72^{\circ} \mathrm{C}$ for $30 \mathrm{~s}$. This was followed by $5 \mathrm{~min}$ final extension at $72^{\circ} \mathrm{C}$. The amplicon size was 333bp (Figure 8).

\section{Species-specific PCR assay}

The published primer sequence by Bottet.al, 2009 was used for amplification of Oesophagostomum columbianum and for Oesophagostomum venulosum the primer sequence was taken from the research article published by Bandyopadhyay et al., (2009). Table 2 gives the detail of primer sequence and amplicon size of $O$. columbianum and $O$. venulosum.

The reaction was performed with the following conditions. Initial denaturation at $94^{0} \mathrm{C}$ for 5 minutes, followed by 35 cycles of $94^{0} \mathrm{C}$ for $30 \mathrm{~s}$ (denaturation), $55^{\circ} \mathrm{C}$ for $30 \mathrm{~s}$ (annealing) and $72^{\circ} \mathrm{C}$ for $30 \mathrm{~s}$ (extension), followed by a final extension at $72{ }^{\circ} \mathrm{C}$ for 7 minutes for $O$. columbianum (Bottet.al., 2009 and Tan et al., 2014) and initial denaturation at $94^{\circ} \mathrm{C}$ for $5 \mathrm{~min}$ followed by 40 cycles of $94^{\circ} \mathrm{C}$ for $1 \mathrm{~min}, 58^{\circ} \mathrm{C}$ for $1 \mathrm{~min}, 72^{\circ} \mathrm{C}$ for 2 min succeeded by final extension at $72^{0} \mathrm{C}$ for 7 minutes for $O$. venulosum. The amplicon size for $O$. columbianum was $251 \mathrm{bp}$ (Figure 9), whereas for $O$. venulosum 182bp (Figure 10).

\section{Results and Discussion}

The present study was set out to investigate the distribution of gastrointestinal nematode parasites on sheep farms of Hassan district 
and to ascertain which species developed resistance to anthelmintics. Faecal samples of 45 farms were screened for gastrointestinal nematode infections. Out of 45 farms, 26 farms were treated with fenbendazole and 19 farms were treated with ivermectin. Overall, resistance to fenbendazole was found on 15out of 26 Sheep farms and in 19 ivermectin treated farms 2 farms showed resistance.

The overall composition of the pre-treatment coprocultural studies revealed Haemonchus $\mathrm{sp}$. as the most predominant genus followed by Trichostrongylus sp, Oesophagostomum $\mathrm{sp}$, Bunostomum sp and Cooperia sp. The results of post treatment coprocultural studies were as follows, in 15 fenbendazole resistant farms, 12 farms had Haemonchus sp as the predominant larvae and Trichostrongylus $\mathrm{sp}$ was predominant in 3 farms, whereas in 2 ivermectin resistant farms, the predominant larvae was Haemonchus sp (Table 3). Oesophagostomum sp was also identified in post treatment faecal culture of 5 farms but not as pre dominant larvae. The larvae of Haemonchus sp. had bullet shaped head and sheath tail extension (STE) with a short filament, a sharp kink was observed posterior to the end of the larval tail (Figure 1), Trichostrongylus spp. were having rounded head and the STE without a filament and tapered sharply like a sharpened wooden pencil (Figure 2). Oesophagostomum sp. have square shaped head and caudal end has a very long filament (Figure 3). In case of bunostomum larva head is bullet shaped and is uniformly stained, STE with a filament (Figure 4). In cooperia the head is bullet shaped with two refractile bodies and the tail sheath is with a finer tip (Figure 5).

In the present study, the faecal coprocultures revealed Haemonchus sp as the predominant parasite of sheep in Hassan district. The result is supported by the reports from many other tropical countries. (Keyyu et al., 2002; Vattaa et al., 2006; Kumsa et al., 2009; Nabukenya et al., 2014; Mungube et al., 2015; Atanásio et al., 2017; Paraud et al., 2017). The occurrence of the different species of gastrointestinal nematodes depends on the interaction of host and the infective larvae on the pasture. Numerous factors may influence the predominance of one species over another, including climate, farm management practices and the presence of anthelmintic resistance in one species over others (Vlassoff and McKenna 1994).

The biotic potential of $H$. contortus parasite justified the percentage of infection with this parasite (Nginyi et al., 2001). The number of the infective larvae of Haemonchus sp. on the pasture might be high for the occurrence of increased incidence of the larvae. The present results agree with the findings of Crofton (1957) the author demonstrate a direct association between the incidence and the level of infection, i.e. when the mean number of any particular species per host is low, then the frequency of occurrence of infected hosts is also low. Conversely, with increase in the mean number per host there is an increase (usually to 100\%) in the frequency of infected individuals. One more reason might be Haemonchus sp. adopts to extreme temperature and conditions, the juveniles will prefer to lay the eggs in the adopted conditions. Although moist conditions are optimal for laying eggs, the juveniles will prefer to lay the eggs in dry conditions when given the option between the two(Li et al., 1999).

Farms 14, 19 and 25 had Trichostrongylus sp as pre dominant larvae. The faecal samples from these farms were collected in the month of October. The conditions might be favourable for the survival and transmission of Trichostrongylus larvae. The results were in agreement with Wilmsen et al., (2014), the author concluded that October has mild 
temperature and moderate rainfall, this is best suitable environmental condition for the transmission of $T$. colubriformis. In contrast, high temperatures associated with heavy rainfalls that occur during summer cause a decline in $T$. colubriformis transmission. It could be also due to lower susceptibility of the Trichostrongylus sp. to fenbendazole in these farms.

In the post treatment faecal cultures the genus Oesophagostomum was found in 5 farms but they were not the predominant larvae.

Polymerase chain reaction was carried out for the larvae isolated from the post treatment faecal cultures of the resistant farms for the confirmation of the species involved in the anthelmintic resistance.

ITS-2 gene was targeted for the confirmation of the species. ITS- 2 has been widely used and has become a useful tool for species identification because it is highly species specific, has more conservative regions and has universal primers binding to the $5.8 \mathrm{~S}$ and $28 \mathrm{~S}$ ribosomal DNA genes of several nematodes (Heise et al., 1999).

The PCR confirmed the presence of Haemonchus contortus in 12 farms which were resistant to fenbendaole and 2 farms resistant to ivermectin. The species specific product of expected size 265bp was amplified
(Figure 6). The results were in agreement with the findings of Hassan et al., (2017) and Almedia et al., (2018), they recorded $H$. contortus as predominant species involved in the resistance. The resistance must be due to prolonged and continuous use of the drug in the farm, under dosing or overdosing of the drug. With the use of the PCR technique, it was determined that the species surviving treatment in the farms 14, 19 and 24 was $T$. colubriformis. Trichostrongylus colubri formis was the second most important parasite. The results are consistent with the findings of Waghorn et al., 2014. This could be due to the lower susceptibility of the parasite to fenbendazole.

Even though genus Oesophagostomum was not found as a predominant parasite in the post treatment faecal cultures, PCR was carried out to know the species involved. $O$. columbianum was the species detected in farm no 12, 19 and 22, whereas in farm no 16 and 27 the species involved was $O$. venulosum. In the faecal culture the larvae were identified only to the genus level. The results were in agreement with findings of Bhandhyopadhyay et al., 2009. The author developed multiplex- PCR assay for identification of parasitic eggs of Oesophagostomum sp. in sheep and goats, in contrary in the current study the molecular assay was adopted for the identification of larvae in the faecal culture.

Table.1 Species specific primers, two generic primers used in the multiplex PCR technique with the amplicon product sizes

\begin{tabular}{|l|l|l|l|}
\hline $\begin{array}{l}\text { Sl. } \\
\text { No }\end{array}$ & Primer target & Sequence & $\begin{array}{l}\text { Amplicon } \\
\text { size (bp) }\end{array}$ \\
\hline $\mathbf{1}$ & $\begin{array}{l}\text { Generic forward } \\
\text { Generic reverse }\end{array}$ & $\begin{array}{l}\text { 5' CACGAATTGCAGACGCTTAG 3' } \\
\text { 5' GCTAAATGATATGCTTAAGTTCAGC3' }\end{array}$ & 398 \\
\hline $\mathbf{2}$ & T. colubriformis & $\mathbf{5}^{\prime}$ ACATCATACAGGAACATTAATGTCA 3' & 232 \\
\hline $\mathbf{3}$ & T.axei & $\mathbf{5}^{\prime}$ GATGTTAATGTTGAACGACATTAATATC 3' & 186 \\
\hline
\end{tabular}


Table.2 Species specific primers and amplicon size for the $O$. columbianum and $O$. venulosum

\begin{tabular}{|l|l|c|}
\hline Species & Sequence & $\begin{array}{c}\text { Amplicon size } \\
\text { (bp) }\end{array}$ \\
\hline o. coumbianum & $\begin{array}{l}\text { Forward- 5' TGTCGAACGATGCTTGCT3' } \\
\text { Reverse- 5'- TTAGTTTCTTTCCTCCGCT -3' }\end{array}$ & $\mathbf{2 5 1}$ \\
\hline o. venulosum & $\begin{array}{l}\text { Forward- 5'CGTGTGTGTGATCCTCGTTC3' } \\
\text { Reverse- 5' CGGTTGTCTCATTTCACAGG 3' }\end{array}$ & $\mathbf{1 8 2}$ \\
\hline
\end{tabular}

Table.3 Farms resistant to fenbendazole and ivermectin with pre dominant larvae in post treatment faecal culture

\begin{tabular}{|c|c|c|c|c|c|c|}
\hline \multirow[t]{2}{*}{$\begin{array}{l}\text { Sl. } \\
\text { NO }\end{array}$} & \multirow[t]{2}{*}{$\begin{array}{l}\text { Resistant } \\
\text { Farm No }\end{array}$} & \multirow[t]{2}{*}{ Drug used } & \multicolumn{3}{|c|}{$\begin{array}{l}\text { larvae present in post treatment } \\
\text { culture ( } 100 \text { randomly selected larvae) }\end{array}$} & \multirow{2}{*}{$\begin{array}{l}\text { Predominant } \\
\text { larvae present in } \\
\text { post treatment } \\
\text { culture }\end{array}$} \\
\hline & & & $\begin{array}{l}\text { Haemon } \\
\text { chus sp }\end{array}$ & $\begin{array}{l}\text { Tricho } \\
\text { strongylus sp }\end{array}$ & $\begin{array}{l}\text { Oesophag } \\
\text { ostomum sp }\end{array}$ & \\
\hline 1 & 1 & Fenbendazole & 68 & 32 & 0 & Haemonchus sp \\
\hline 2 & 2 & Fenbendazole & 73 & 27 & 0 & Haemonchus sp \\
\hline 3 & 5 & Fenbendazole & 88 & 12 & 0 & Haemonchus sp \\
\hline 4 & 9 & Fenbendazole & 77 & 23 & 0 & Haemonchus sp \\
\hline 5 & 11 & Fenbendazole & 84 & 16 & 0 & Haemonchus sp \\
\hline 6 & 12 & Fenbendazole & 60 & 24 & 16 & Haemonchus sp \\
\hline 7 & 13 & Fenbendazole & 69 & 31 & 0 & Haemonchus sp \\
\hline 8 & 14 & Fenbendazole & 22 & 78 & 0 & Trichostrongylus sp \\
\hline 9 & 16 & Fenbendazole & 65 & 22 & 13 & Haemonchus sp \\
\hline 10 & 18 & Fenbendazole & 66 & 34 & 0 & Haemonchus sp \\
\hline 11 & 19 & Fenbendazole & 11 & 83 & 6 & Trichostrongylus sp \\
\hline 12 & 20 & Fenbendazole & 88 & 12 & 0 & Haemonchus sp \\
\hline 13 & 22 & Fenbendazole & 79 & 12 & 9 & Haemonchus sp \\
\hline 14 & 25 & Fenbendazole & 35 & 65 & 0 & Trichostrongylus sp \\
\hline 15 & 27 & Fenbendazole & 66 & 20 & 14 & Haemonchus sp \\
\hline 16 & 31 & Ivermectin & 88 & 12 & 0 & Haemonchus sp \\
\hline 17 & 37 & Ivermectin & 66 & 34 & 0 & Haemonchus sp \\
\hline
\end{tabular}

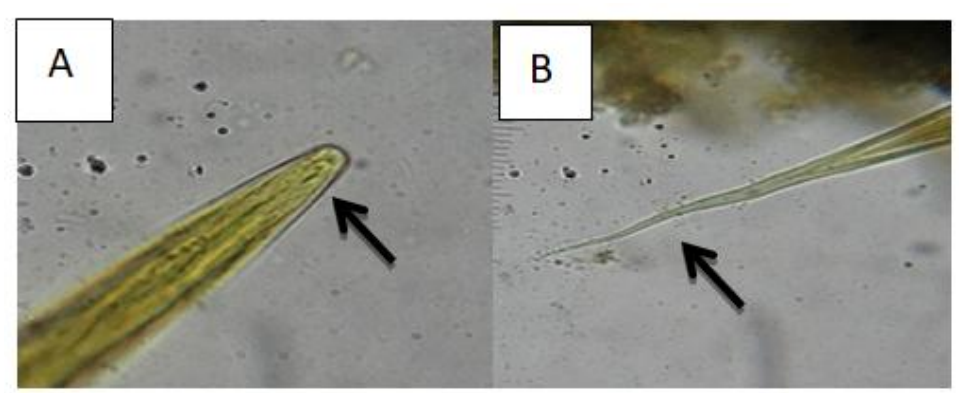

Figure.1 Haemonchus contortus $\mathrm{L}_{3}$ larvae: (A) Cranial end showing bullet shaped head, (B) Caudal end showing a short filament with a kinked tail 


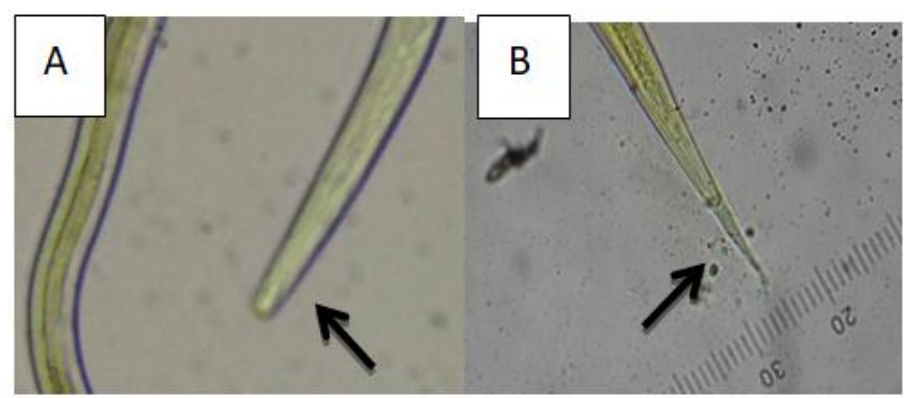

Figure.2 Trchostrongylus $\mathrm{L}_{3}$ larvae: (A) Cranial end showing rounded head, (B) Caudal end without filament

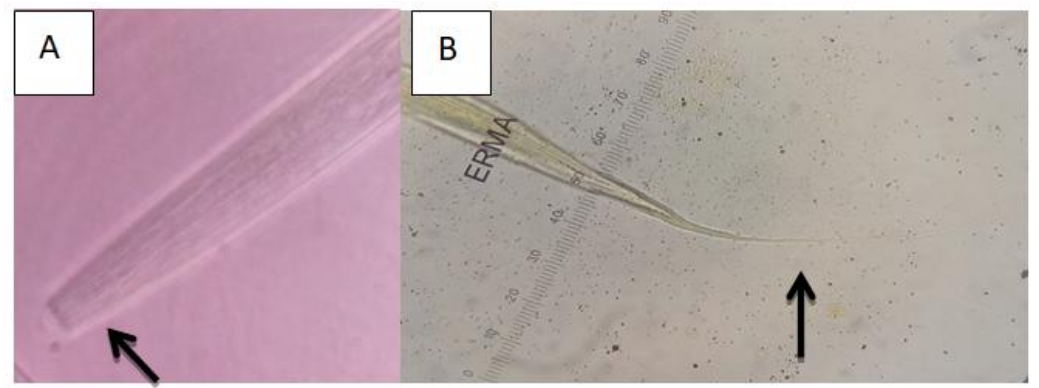

Figure.3 Oesophagostomum $\mathrm{L}_{3}$ larvae: (A) Cranial end showing squareded head, (B) Caudal end with long filament

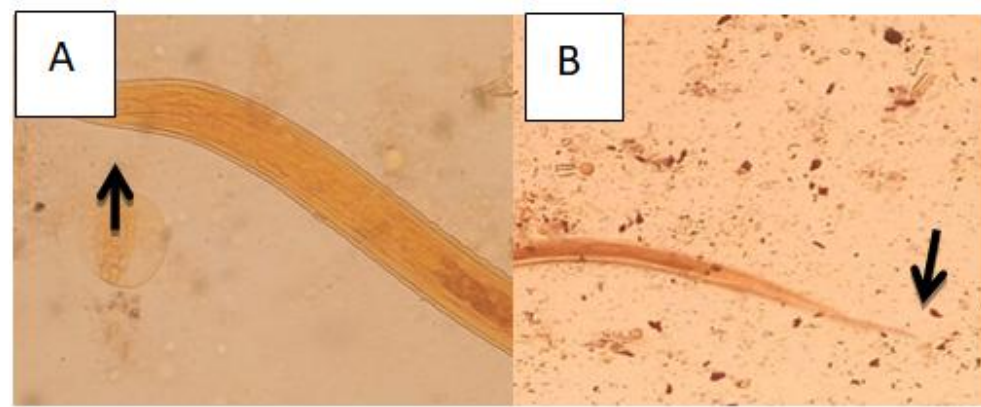

Figure.4 Bunostomum $\mathrm{L}_{3}$ larvae: (A) Cranial end showing bullet shaped head, stains uniformly dark brown with iodine (B) Sheath tail extension with a filament

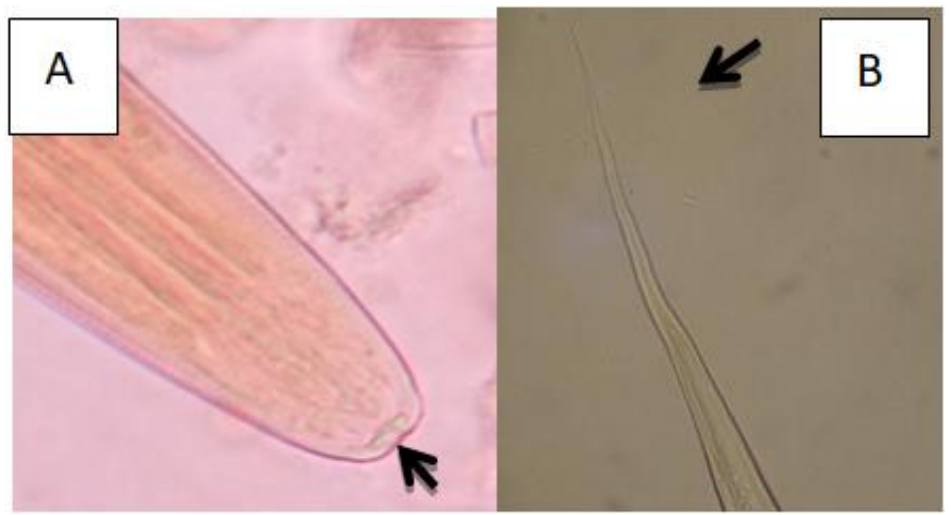

Figure.5 Cooperia $\mathrm{L}_{3}$ larvae: (A) Cranial end showing two refractile bodies, stains uniformly dark brown with iodine (B) Caudal end showing tail sheath with finer tip 


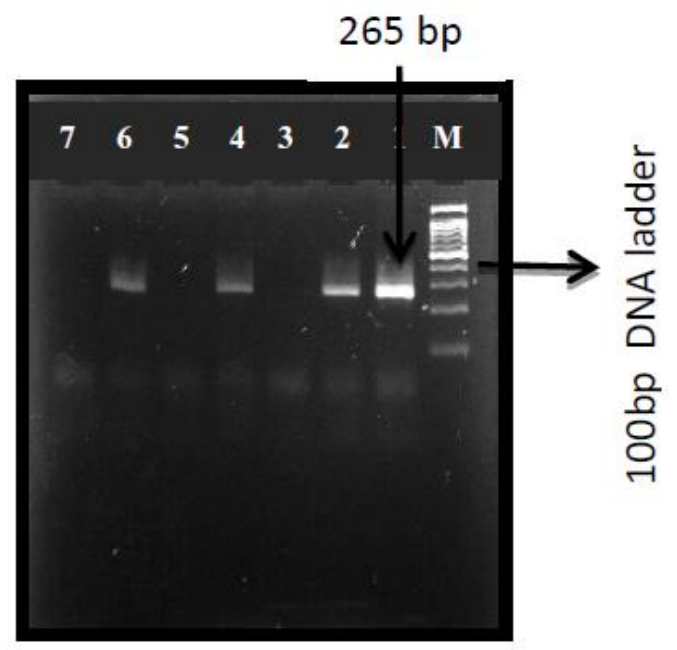

Figure.6 Lane 1, 2, 4, 6: ITS-2 gene amplicons of $H$. contortus (265 bp)

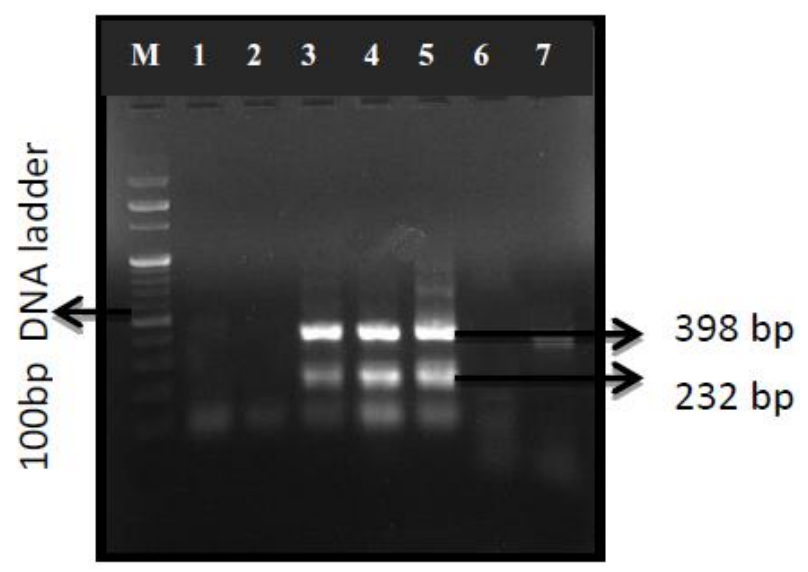

Figure.7 Lane 3, 4, 5, 7: Trichostrongylus sp. of 398 bp Lane 3, 4, 5: ITS-2 gene amplicons of T. colubriformis (232 bp)

$333 \mathrm{bp}$

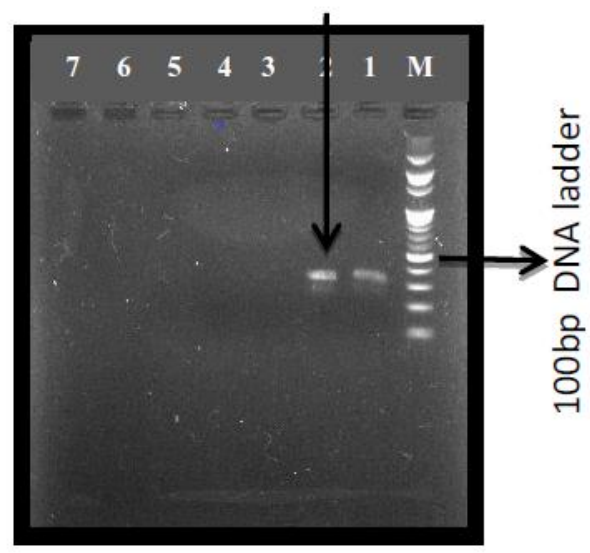

Figure.8 Lane 1, 2: ITS-2 gene amplicons of Oesophagostomum sp (333 bp)

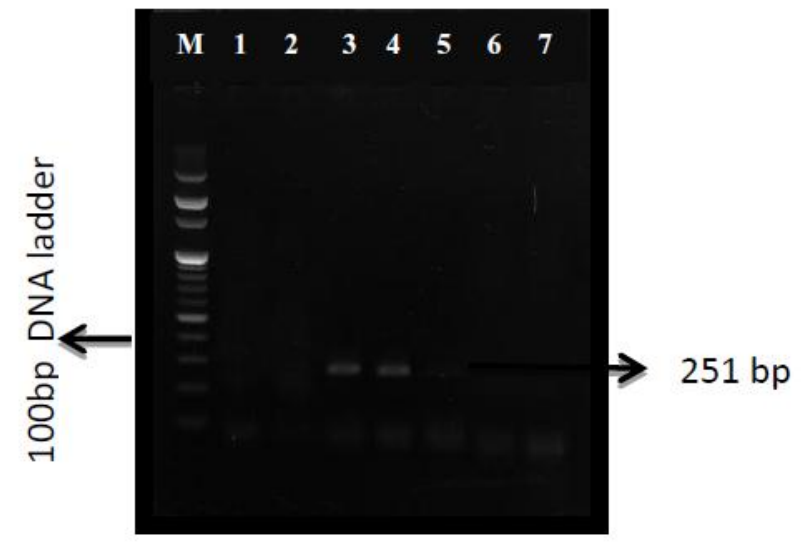

Figure.9 Lane 3, 4, 5 : ITS-2 gene amplicons of $O$. columbianum $(251 \mathrm{bp})$ 
$182 \mathrm{bp}$

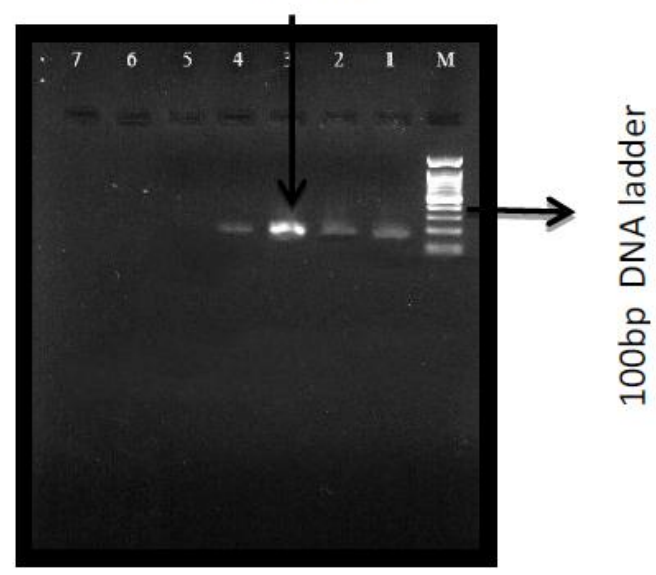

Figure.10 Lane 1, 2, 3, 4: ITS-2 gene amplicons of O. venulosum (182 bp)

The morphological characterization of the larvae removes the considerable cost of slaughtering the animals. Nevertheless the use of only morphological characters in identification may lead to inaccurate results, particularly if two or more species are sympatric and have only minor morphological differences. Molecular identification of larva by PCR prevents misdiagnosis. Recent studies have delivered advanced PCR tools for epidemiological studies and to support investigations in combination with conventional parasitological techniques. The molecular assays help to overcome the constraints of traditional methods.

\section{References}

Almeida, F. A., Bassetto, C. C., Amarante, M. R. V., Albuquerque, A. C. A., Starling, R. Z. C. and Amarante, A. F. T. 2018. Helminth infections and hybridization between Haemonchus contortus and Haemonchu splacei in sheep from Santana do Livramento, Brazil. Braz. J. Vet. Parasitol. 27(3): 280-288.

Atanásio, N. A., Ayres, M. C. C., Lambert, S. M. and Souza, B. P. 2017. Anthelmintic resistance in gastrointestinal nematodes of goats in southern Mozambique. J.
Vet. Med. Anim. Health. 9 (11): 313319.

Bandyopadhyay, S., Naskar, S., Devi, P., Bera, A. K., De1, S., Pan, D., Rana, T., Das, S., Sikdar, S. and Bhattacharya, D. 2009. Multiplex PCR for Identification of Parasitic Eggs of Oesophagostomum spp. Isolated from Sheep and Goat. Proc. zool. Soc.62 (2): 125-129.

Bott, N. J., Campbell, E. B., Beveridge, I., Chilton, N. B., Ress, D., Hunt, P. W. and Gasser, R. B. 2009. A combined microscopic-molecular method for the diagnosis of strongylid infections in sheep: International Journal for Parasitology 39: 1277-1287.

Coles, G. C., Jackson, F., Pomroy, W. E., Prichard, R. K., Von SamsonHimmelstjerna, G., Silvestre, A., Taylor, M. A. and Vercruysse, J. 2006.The detection of anthelmintic resistance in nematodes of veterinary importance. Vet. Parasitol.136: 167-85.

Coop, R. L., Holmes, P. H. 1996. Nutrition and parasite interaction. Int. J. Parasitol. 26: 951-62.

Crofton, H. D. 1957. Nematode parasite populations in sheep on low- land farms. III. The seasonal incidence of species. I. bid. 47: 304-18. 
Hassan, S. A., Mohammed, A. A. and Omer, F. A. 2017. Molecular method to diagnosis of some strongylide nematode of goats in Nyala area South Darfur State- Sudan. Journal of Agriculture and Veterinary Science. 10(4): 54-56.

Hayat, C. S., Hussain, S. M., Iqbal, Z., Hayat, B. and Akhtar, M. 1996, Effect of parasitic nematodes on haematology and productivity of sheep. Pak. Vet. J. 16: 81-3.

Heise, M., Epe, C. and Schnieder, T. 1999. Differences in the Second Internal Transcribed spacer (ITS-2) of Eight species of Gastrointestinal Nematodes of Ruminants. The Journal of Parasitology.85(3): 431435.doi:10.2307/3285774

Keyyu, J. D., Mahingika, H. M., Magwisha, H. B. and Kassuku, A. A. 2002. Efficacy of albendazole and levamisole against gastrointestinal nematodes of sheep and goats in Morogoro, Tanzania. Trop. Anim. Health. Prod. 34(2): 115120.

Kumar, B. D., Sankar, M., Kumar, R., Kumar, A., Kadian, P., Bhawana Kushwaha, Parthasarathi, B.C., Khare, R. K. and Chandra, D. 2018. Molecular Identification of Oesophagostomum spp. from Himalayan Grey Langur. Int.J.Curr.Microbiol.App.Sci. 7(3): 146151.

Kumsa, B. and Abebe, G. 2009. Multiple anthelmintic resistance on a goat farm in Hawassa (southern Ethiopia). Trop. Anim. Health. Prod. 41(4): 655-662.

Li, J., Zhu, X., Boston, R., Ashton, F. and Gamble, H. 1999. The neurobiology of host-finding behavior in animal parasitic nematodes: thermotaxis and thermosensory neurons in infective larvae of Haemonchus contortus, a passively ingested species" (On-line). Accessed 09/23/04 at http://www.nal.usda.gov/ttic/tektran/d ata/000010/82/0000108208.html.

Mungube, E., Wamae, L., Omondi, G. and Mwangi, G. 2015. Prevalence of multiple resistant Haemonchus and Ostertagia species in goats and cattle in Machakos, eastern Kenya. Livestock. Res. Rural. Dev. 27(12): 288.

Nabukenya, I., Rubaire-Akiiki, C., Olila, D., Muhangi, D. and Höglund, J. 2014. Anthelmintic resistance in gastrointestinal nematodes in goats and evaluation of FAMACHA diagnostic marker in Uganda. Vet. Parasitol. 205(3): 666-675.

Nginyi, J. M., Duncan, J. L., Mellor, D. J., Stear, M. J., Wanyangu, S. W. Bain, R. K. and Gatongi, P. M. 2001. Epidemiology of parasitic gastrointestinal nematode infections of ruminants on smallholder farms in central Kenya. Res. Vet. Sci. 70: 33-39.

Paraud, C. and Chartier, C. 2017. Facing anthelmintic resistance in goats. In: Simões J, Gutiérrez C, editors. Sustainable goat production in adverse environments: welfare, health and breeding. Vol 1, Cham(Ed): springer International Publishing., pp. 267-292.

Pugh, D. G. and Baird, N. 2012. Sheep \& goat medicine. USA: Elsevier Health Sciences. pp. 216-238.

Singh, S. and Yadav, C. L. 1997. A Survey of Anthelmintic Resistance by Nematodes on Three Sheep and Two Goat Farms in Hisar (India). Veterinary Research Communications. 21(6): 447-51.

Soulsby, E. J. L.Helminths, arthropods and protozoa of domesticated animals. Sixth edition of Monnig's Veterinary Helimnthology and Entomology. Bailliere, Tindall and Cassell, London, England 1971.

Suarez, V. H., Cristel, S. L. and Busetti, M. R. 2009. Epidemiology and effects of 
gastrointestinal nematode infection on milk productions of dairy ewes. Parasite. 16: 141-7.

Sweeny, J. P. A., Ryan, U. M. and Robertson, I. D. 2012.Molecular identification of naturally acquired strongylid infections in lambs-An investigation into how lamb age influences diagnostic sensitivity. Vet. Parasitol.187: 227-36.

Tan. T. K., Panchad, .C., Lee, L.V., Ngui R., Sharma, S. K. R. and Lim, A. L. Y. 2014. Co-infection of Haemonchus contortus and Trichostrongylus spp among livestock in Malaysia as reveled by amplification and sequencing of internal transcribed spacer $\Pi$ DNA region. MBC Veterinary Research. $10: 38$.

Urquhart, G. M., Aremour, J., Dunchan, J. L., Dunn, A. M. and Jeninis, F. W. 1996. Veterinary parasitology 2thedition, The University of Glasgow, Blackwell sciences, Scotland, 3-137.

Van Wyk, J. A., Cabaret, J. and Michael, L. M. 2004.Morphological identification of nematode larvae of small ruminants and cattle simplified. Vet. Parasitol. 119: 277-306.

Van Wyk, J.A. \& Mayhew, E. 2013, Morphological identification of parasitic nematode infective larvae of small ruminants and cattle: A practical lab guide. Onderstepoort Journal of Veterinary Research. 80(1): Art. \#539, 14 pages.

Vattaa, A. F. and Lindberg, A. L. 2006. Managing anthelmintic resistance in small ruminant livestock of resourcepoor farmers in South Africa. J. S. Afr. Vet. Assoc. 77(1): 2-8.

Vlassoff, A. and McKenna, P. B. 1994. Nematode parasites of economic importance in sheep in New Zealand. New Zealand Journal of Zoology. 21: 18.

Waghorn, T. S., Knight, J. S. and Leathwick, D. M. 2013. The distribution and anthelmintic resistance status of Trichostrongylus colubriformis, $T$. vitrinus and T. axei in lambs in New Zealand. New Zealand Veterinary Journal. 62(3): 152-159. DOI: 10.1080/00480169.2013.871193.

Wilmsen, M. O., Silva, B. F., Bassetto, C. C. and Amarante, A. F. T. 2014. Gastrointestinal nematode infections in sheep raised in Botucatu, state of São Paulo, Brazil. Braz. J. Vet. Parasitol. 23(3): 348-354.

\section{How to cite this article:}

Veena, M., G. C. Puttalakshmamm, K. J. Ananda and Sengupta, P. P. 2020. Morphological and Molecular Characterization of Gastrointestinal Nematodes in Sheep. Int.J.Curr.Microbiol.App.Sci. 9(04): 2564-2575. doi: https://doi.org/10.20546/ijcmas.2020.904.308 